\title{
THE POST-CORONA EPILOGUE OF AN OVERHEATED SINO-AMERICAN RELATIONSHIP: WE HAVE A WINNER, WILL WE HAVE A GAME-CHANGER TOO?
}

\author{
Anis H. BAJREKTAREVIĆ, \\ University of Vienna
}

\begin{abstract}
On the eastern, ascendant flank of the Eurasian continent, the Chinese vertigo economy is overheated and too-well integrated in the petrodollar system. Beijing, presently, cannot contemplate or afford to allocate any resources in a search for an alternative. (The Sino economy is a low-wage- and labor intensive- centered one. Chinese revenues are heavily dependent on exports and Chinese reserves are predominantly a mix of the USD and US Treasury bonds.) To sustain itself as a single socio-political and formidably performing economic entity, the People's Republic requires more energy and less external dependency. Domestically, the demographic-migratory pressures are huge, regional demands are high, and expectations are brewing. Chine is a challenger that (for the time being) wishes to preserve the status quo, while the US is a status quo power that wants to challenge the system by decoupling. What will be the end game; yet another winner or a game-changer?
\end{abstract}

Keywords: US, China, Trade, International System, bio-warfare, history of currencies.

\section{Introduction}

Americans performed three very different policies on the People's Republic: From a total negation (and the Mao-time mutual annihilation assurances), to Nixon's sudden cohabitation. Finally, a Copernican-turn: the US spotted no real ideological differences between them and the post-Deng China. This signalled a 'new opening': West imagined China's coastal areas as its own industrial suburbia. Soon after, both countries easily agreed on interdependence (in this marriage of convenience): Americans pleased their corporate (machine and tech) sector and unrestrained its greed, while Chinese in return offered a cheap labour, no environmental considerations and submissiveness in imitation.

However, for both countries this was far more than economy, it was a policy - Washington read it as interdependence for transformative containment and Beijing sow it as interdependence for a (global) penetration. In the meantime, Chinese acquired more sophisticated technology, and the American Big tech sophisticated itself in digital authoritarianism - 'technological monoculture' met the political one. But now with a tidal wave of Covid-19, the honeymoon is over. These days,

31 Contact address: anis@corpsdiplomatique.cd 
many argue that our $\mathrm{C}-19$ response is a planetary fiasco, whose size is yet to surface with its mounting disproportionate and enduring secondary effects. All this illustrates - the argument goes - nothing else but the non-transparent concentration of power and our overall democracy recession; lasting consequences of cutbacks, environmental holocaust, privatisation of key intergovernmental and vital national institutions, ill-fated globalisation on (overly allopathic, mandated drugs -centred) healthcare, and luck of public data commons. Pandemic or plundemic ...

There are also growing speculations if the lockdown is invasion or protection - whether the aim is a herd-immunity or herd loyalty; if is there any back-to-normal exit from the crisis or this disaster 'turned into planetary terror, through global coup d'état' will be exploited to further something already pre-designed (with a fear, not as a side-effect, but rather as a manufactured tool to gain control). E.g. Le Monde Diplomatique - while examining the possible merge between tech oligopoly and political monopoly - claims: "Political decisions have been central in shaping this tragedy - from the destruction of animal habitats, to the asymmetric funding of medical research, to the management of the crisis itself. They will also determine the world into which we emerge after the worst is over." The XXI century frontline is the right to health and labour, privacy and human rights. (LMD, IV20)

Still to be precise, the so-called virus pandemic brought nothing truly new to the already overheated Sino-American relations: It only amplified and accelerated what was present for quite some time - a rift between alienated power centers, each on its side of Pacific, and the rest. Is this time to return to a nation-state, a great moment for all dictators-in-waiting to finally build a cult of personality? Hence, will our democracy be electro-magnetised and vaccinated for a greater good (or greedier 'god')?

This text examines a prehistory of that rift; and suggests possible outcomes past the current crisis. Does our history only appear overheated, while it is essentially calmly predetermined? Is it directional or conceivable, dialectic and eclectic or cyclical, and therefore cynical? Surely, our history warns (no matter if the Past is seen as a destination or resource). Does it also provide for a hope? Hence, what is in front of us: destiny or future? Theory loves to teach us that extensive debates on what kind of economic system is most conductive to human wellbeing is what consumed most of our civilizational vertical. However, our history has a different say: It seems that the manipulation of the global political economy - far more than the introduction of ideologies - is the dominant and arguably more durable way that human elites usually conspired to build or break civilizations, as planned projects. Somewhere down the process, it deceived us, becoming the self-entrapment. How?

One of the biggest (nearly schizophrenic) dilemmas of liberalism, ever since David Hume and Adam Smith, was an insight into reality: Whether the world is essentially Hobbesian or Kantian. As postulated, the main task of any liberal state is to enable and maintain wealth of its nation, which of course rests upon wealthy individuals inhabiting the particular state. That imperative brought about another dilemma: if wealthy individual, the state will rob you, but in absence of it, the pauperized masses will mob you. 
The invisible hand of Smith's followers have found the satisfactory answer - sovereign debt. That 'invention' meant: relatively strong central government of the state. Instead of popular control through the democratic checks- $\&$-balance mechanism, such a state should be rather heavily indebted. Debt - firstly to local merchants, than to foreigners - is a far more powerful deterrent, as it resides outside the popular check domain. With such a mixed blessing, no empire can easily demonetize its legitimacy, and abandon its hierarchical but invisible and unconstitutional controls. This is how a debtor empire was born. A blessing or totalitarian curse? Let us briefly examine it.

The Soviet Union - much as (the pre-Deng's) China itself - was far more of a classic continental military empire (overtly brutal; rigid, authoritative, anti-individual, apparent, secretive), while the US was more a financial-trading empire (covertly coercive; hierarchical, yet asocial, exploitive, pervasive, polarizing). On opposite sides of the globe and cognition, to each other they remained enigmatic, mysterious and incalculable: Bear of permafrost vs. Fish of the warm seas. Sparta vs. Athens. Rome vs. Phoenicia... However, common for the both (as much as for China today) was a super-appetite for omnipresence. Along with the price to pay for it. Consequently, the Soviets went bankrupt by mid 1980s - they cracked under its own weight, imperially overstretched. So did the Americans - the 'white man burden' fractured them already by the Vietnam war, with the Nixon shock only officializing it. However, the US imperium managed to survive and to outlive the Soviets. How? The United States, with its financial capital (or an outfoxing illusion of it), evolved into a debtor empire through the Wall Street guaranties. Titanium-made Sputnik vs. gold mine of printed-paper... Nothing epitomizes this better than the words of the longest serving US Federal Reserve's boss, Alan Greenspan, who famously quoted J.B. Connally to then French President Jacques Chirac: "True, the dollar is our currency, but your problem". Hegemony vs. hegemoney.

\section{House of Cards}

Conventional economic theory teaches us that money is a universal equivalent to all goods. Historically, currencies were a space and time-related, to say locality-dependent. However, like no currency ever before, the US dollar became - past the WWII - the universal equivalent to all other moneys of the world. According to history of currencies, the core component of the non-precious metals' money is a so-called promissory note - intangible belief that, by any given point in future, a particular shiny paper (self-styled as money) will be smoothly exchanged for real goods. Thus, roughly speaking, money is nothing else but a civilizational construct about imagined/projected tomorrow - that the next day (which nobody has ever seen in the history of humankind, but everybody operates with) definitely comes (i), and that this tomorrow will certainly be a better day then our yesterday or even our today (ii).

This and similar types of collective constructs (horizontal and vertical) over our social contracts hold society together as much as its economy keeps it alive and evolving. Hence, it is money that powers economy, but our blind faith in constructed (imagined) tomorrows and its alleged certainty is what empowers money.

Clearly, the universal equivalent of all equivalents - the US dollar - follows the same pattern: Bold and widely accepted promise. For the US, it almost instantly substantiates extraterritorial 
economic projection: American can print (any sum of) money without fear of inflation. (Quantitative easing is always exported, value is kept home.)

But, what does the US dollar promise when there is no gold cover attached to it ever since the time of Nixon shock of 1971? Pentagon promises that the oceanic sea-lanes will remain opened (read: controlled by the US Navy), pathways unhindered, and that the most traded world's commodity - oil, will be delivered. So, it is not a crude or its delivery what is a cover to the US dollar - it is a promise that oil of tomorrow will be deliverable. That is a real might of the US dollar, which in return finances Pentagon's massive expenditures and shoulders its supremacy. Admired and feared, Pentagon further fans our planetary belief in tomorrow's deliverability - if we only keep our faith in dollar (and hydrocarbons' energized economy), and so on and on in perpetuated circle of mutual reinforcements. (Supplementing the Monroe Doctrine, President Howard Taft introduced the so-called 'dollar diplomacy' - in early XX c. - that "substitutes dollars for bullets". This is one of the first official acknowledgements of the Wall Street - Pentagon symbiotic link.)

These two pillars of the US might from the East coast (the US Treasury/Wall Street and Pentagon) together with the two pillars of the West coast - both financed and amplified by the US dollar, and spread through the open sea-routs (Silicone Valley and Hollywood), are an essence of the US posture.

This very nature of power explains why the Americans have missed to take the mankind into completely other direction; towards the non-confrontational, decarbonized, de-monetized/de-financialized and de-psychologized, the self-realizing and green humankind. In short, to turn history into a moral success story. They had such a chance when, past the Gorbachev's unconditional surrender of the Soviet bloc, and the Deng's Copernicus-shift of China, the US - unconstrained as a lonely superpower - solely dictated terms of reference; our common destiny and direction/s to our future/s.

\section{Winner is Rarely a Game-Changer}

Sadly enough, that was not the first missed opportunity for the US to soften and delay its forthcoming, imminent multidimensional imperial retreat. The very epilogue of the WWII meant a full security guaranty for the US: Geo-economically - $54 \%$ of anything manufactured in the world was carrying the Made in USA label, and geostrategically - the US had uninterruptedly enjoyed nearly a decade of the 'nuclear monopoly'. Up to this very day, the US scores the biggest number of $\mathrm{N}$-tests conducted, the largest stockpile of nuclear weaponry, and it represents the only power ever deploying this 'ultimate weapon' on other nation. To complete the irony, Americans enjoy geographic advantage like no other empire before. Save the US, as Ikenberry notes: "...every major power in the world lives in a crowded geopolitical neighborhood where shifts in power routinely provoke counterbalancing". Look the map, at Russia or China and their packed surroundings. The US is blessed with its insular position, by neighboring oceans. All that should harbor tranquility, peace and prosperity, foresightedness.

Why the lonely might, an empire by invitation did not evolve into empire of relaxation, a generator of harmony? Why does it hold (extra-judicially) captive more political prisoners on 
Cuban soil than the badmouthed Cuban regime has ever had? Why does it remain obsessed with armament for at home and abroad? Why existential anxieties for at home and security challenges for abroad? Eg. 78\% of all weaponry at disposal in the wider MENA theater is manufactured in the US, while domestically Americans - only for their civilian purpose - have 1.2 small arms pieces per capita.)

Why the fall of Berlin Wall 30 years ago marked a beginning of decades of stagnant or failing incomes in the US (and elsewhere in the OECD world) coupled with alarming inequalities. What are we talking about here; the inadequate intensity of our tireless confrontational push or about the false course of our civilizational direction?

Indeed, no successful and enduring empire does merely rely on coercion, be it abroad or at home. The grand design of every empire in past rested on a skillful calibration between obedience and initiative - at home, and between bandwagoning and engagement - abroad. In XXI century, one wins when one convinces not when one coerces. Hence, if unable to escape its inner logics and deeply-rooted appeal of confrontational nostalgia, the prevailing archrival is only a winner, rarely a game-changer.

\section{A Country or a Cause, Both or None?}

To sum up: after the collapse of the Soviet Union, Americans accelerated expansion while waiting for (real or imagined) adversaries to further decline, 'liberalize' and bandwagon behind the US. One of the instruments was to aggressively push for a greater economic integration between regional and distant states, which - as we see now, passed the 'End-of-History' euphoria of 1990s - brought about (irreversible) socio-political disintegration within each of these states.

Expansion is the path to security dictatum, of the post-Cold War socio-political and economic mantra, only exacerbated the problems afflicting the Pax Americana. That is how the capability of the US to maintain its order started to erode faster than the capacity of its opponents to challenge it. A classical imperial self-entrapment!! The repeated failure to notice and recalibrate its imperial retreat brought the painful hangovers to Washington, the most noticeably, by the last presidential elections. Inability to manage the rising costs of sustaining the imperial order only increased the domestic popular revolt and political pressure to abandon its 'mission' altogether. Perfectly hitting the target to miss everything else ...

Hence, Americans are not fixing the world anymore. They are only managing its decline. Look at their footprint in former Yugoslavia, Afghanistan, Iraq, Pakistan, Georgia, Libya, Syria, Ukraine or Yemen - to mention but a few.

When the Soviets lost their own indigenous ideological matrix and maverick confrontational stance, and when the US dominated West missed to triumph although winning the Cold War, how to expect from the imitator to score the lasting moral or even a temporary economic victory? Dislike the relationship with the Soviets Union which was on one clear confrontational acceptance line from a start until its very last day, Americans performed three very different policies on the People's Republic: From a total negation (and the Mao-time mutual annihilation assurances), to Nixon's sudden cohabitation. Finally, a Copernican-turn: the US spotted no real ideological differences 
between them and the post-Deng China. This signalled a 'new opening' - China's coastal areas to become West's industrial suburbia. Soon after, both countries easily agreed on interdependence: Americans pleased their corporate (machine and tech) sector and unrestrained its greed, while Chinese in return offered a cheap labour, no environmental considerations and submissiveness in imitation. However, for both it was far more than economy, it was a policy - Washington read it as interdependence for transformative containment and Beijing sow it as interdependence for (global) penetration. In the meantime, Chinese acquired more sophisticated technology, and the American Big tech sophisticated itself in digital authoritarianism.

But, the honeymoon seems over now.

Lasting collision course already leads to the subsequent calls for a decupling of the two world's largest economies. Besides marking the end of global capitalism which exploded since the fall of Berlin Wall, this may finally trigger a global realignment. The rest of the world would end up - willingly or not - in the rival (trade) blocks. It would not be a return to 1950s and 1960s, but to the pre-WWI constellations. Epilog is plain to see: Neither more confrontation and more carbons nor more weaponized trade and traded weapons will save our day. It failed in our past, it will fail again any given day.

\section{Entrapment in Imitation}

Interestingly, China opposed the I World, left the II in rift, and ever since Bandung of 1955 it neither won over nor (truly) joined the III Way. Today, many see it as a main contestant. But, where is a lasting success?

There is a near consensus among the economists that China owes its economic success to three fundamental factors. Firstly, it is that the People's Republic embraced an imitative economic policy (much like Japan, Singapore, Taiwan or ROK did before) through Deng-proclaimed opening. Second goes to a modest domestic consumption, and German-like thick home savings. Finally, as the third factor that the economists attribute to Chinese miracle, is a low production costs of Sino nation - mostly on expenses of its aging demography, and on expenses of its own labor force and country's environment. None of it has an international appeal, nor it holds promise to an attainable future. Therefore, no wonder that the Imitative power fights - for at home and abroad - a defensive ideological battle. Such a reactive status quo has no intellectual appeal to attract and inspire beyond its borders.

So, if for China the XIX was a "century of humiliation", XX "century of emancipation", should it be that the XXI gets labeled as a "century of imitation"? (The Belt and Road Initiative (BRI) is what the most attribute as an instrument of the Chinese planetary posture. Chinese leaders promised massive infrastructure projects all around by burning trillions of dollars. Still, numbers are more moderate. As the recent The II BRI Summit has shown, so far, Chinese companies had invested USD 90 billion worldwide. Seems, neither People's Republic is as rich as many (wish to) think nor it will be able to finance its promised projects without seeking for a global private capital. Such a capital -if ever - will not flow without conditionalities. The Asian Infrastructure Investment Bank (AIIB) and the BRICS or 'New Development' - Bank have some \$150 billion at hand, and 
the Silk Road Infrastructure Fund (SRIF) has up to $\$ 40$ billion. Chinese state and semi-private companies can access - according to the OECD estimates - just another $\$ 600$ billion (much of it tight) from the home, state-controlled financial sector. That means that China runs short on the BRI deliveries worldwide. Ergo, either bad news to the (BRI) world or the conditionalities' constrained China.)

How to behave in the world in which economy is made to service trade (as it is defined by the Sino-American high priests of globalization), while trade increasingly constitutes a significant part of the big power's national security strategy? And, how to define (and measure) the existential threat: by inferiority of ideological narrative - like during the Cold War; or by a size of a lagging gap in total manufacturing output - like in the Cold War aftermath. Or something third? Perhaps a return to an inclusive growth.

For sure, there is no intellectual appeal in a growth without well-being, education that does not translate into fair opportunity, lives without dignity, liberalization without personal freedom. Greening international relations along with a greening of social fabrics and its economy - geopolitical and environmental understanding, de-acidification and relaxation is that missing, third, way for tomorrow.

This necessitates both at once: less confrontation over the art-of-day technology and their de-monopolized redistribution as well as the resolute work on the so-called Teslaian implosive/ fusion-holistic systems. That would include the free-transfer non-Hertzian energy technologies (able to de-toxicate our troposphere from dangerous fields, waves and frequencies emittance bringing it closer to Schumann resonance); carbon-sequestration; antigravity and self-navigational solutions; bioinformatics and nanorobotics. Surely, with the bioinformatics and nanorobotics being free from any usage for eugenics ends (including the vaccination for microchipping purpose).

In short, more of initiative than of obedience (including more public control over data hoovering). More effort to excellence (creation) than a struggle for preeminence (partition). 'Do like your neighbor' is a Biblical-sounding economic prophecy that the circles close to the IMF love to tirelessly repeat. Indeed, it is hard to imagine a formidable national economic prosperity, if the good neighborly relations are not built and maintained. Clearly, no global leader has ever in history emerged from a shaky and distrustful neighborhood, or by offering a little bit more of the same in lieu of an innovative technological advancement. (E.g. many see Chinese $5 \mathrm{C}$ besides the hazardous electrosmog of loT that this technology emits on Earth's biota - as an illiberal innovation, which may end up servicing authoritarianism, anywhere. And indeed, the Al deep learning inspired by biological neurons (neural science) including its three methods: supervised, unsupervised and reinforced learning can end up by being used for the diffusion of digital authoritarianism, predictive policing and manufactured social governance based on the bonus-malus behavioral social credits.)

Ergo, it all starts from within, from at home; socio-economically and environmentally. Without support from a home base (including that of Hong Kong, Xinjiang and Tibet), there is no game changer. China's home is Asia. Its size and its centrality along with its impressive output is constraining it enough. 
Conclusively, it is not only a new, non-imitative, turn of socioeconomics and technology what is needed. Without truly and sincerely embracing mechanisms such as the NaM, ASEAN and SAARC (eventually even the OSCE) and the main champions of multilateralism in Asia, those being India Indonesia and Japan first of all, China has no future of what is planetary awaited - the third force, a game-changer, lasting visionary and trusted global leader.

\section{Post Scriptum}

To varying degrees, but all throughout a premodern and modern history, nearly every world's major foreign policy originator was dependent (and still depends) on what happens in, and to, Russia. So, neither a structure, nor content or overall direction of world affairs for the past 300 years has been done without Russia. It is not only a size, but also a centrality of Russia that matters. That is important as much (if not even more), as it is an omnipresence of the US or a hyperproduction of the PR China. Ergo, that is an uninterrupted flow of manufactured goods to the whole world, it is a balancing of the oversized and centrally positioned one, and it is the ability to controllably corrode the way in and insert itself of the peripheral one. The oscillatory interplay of these three is what characterizes our days.

Therefore, reducing the world affairs to the constellation of only two super-players - China and the US is inadequate - to say least. It is usually done while superficially measuring Russia's overall standing by merely checking its current GDP, and comparing its volume and PPP, and finding it e.g. equal to one of Italy. Through such 'quick-fix', Russia is automatically downgraded to a second-rank power status. This practice is as dangerous as it is highly misleading. Still, that ill-conceived argument is one of the most favored narratives which authors in the West are tirelessly peddling. What many analysts miss to understand, is in fact plain to see; throughout the entire history of Russia: For such a big country the only way to survive - irrespectively from its relative weaknesses by many 'economic' parameters - is to always make an extra effort and remain great power.

To this end, let us quickly contrast the above narrative with some key facts: Russia holds the key positions in the UN and its Agencies as one of its founding members (including the Security Council veto right as one of the P5); it has a highly skilled and mobilized population; its society has deeply rooted sense of a special historic mission (that notion is there for already several centuries - among its intellectuals and enhanced elites, probably well before the US has even appeared as a political entity in the first place). Additionally and tellingly, Moscow possesses the world's largest gold reserves (on surface and underground; in mines and its treasury bars); for decades, it masters its own GPS system and the most credible outer space delivery systems (including the only remaining working connection with the ISS), and has an elaborate turn-keyready alternative internet, too.

Finally, as the US Council of Foreign Relations' Thomas Graham fairly admits: "with the exception of China, no country affects more issues of strategic and economic importance to the US than Russia. And no other country, it must be said, is capable of destroying the US in 30 minutes." (FAM, 98-6-19, pg.134) 


\section{References}

1. Abu-Lughod, J. L. (1989), Before European Hegemony, Oxford: Oxford University Press

2. Acemoglu, D. and Robinson, J.A. (2012), Why Nations Fail, Crown Business (Random House) NY

3. Bajrektarević, A. (2012), What China Wants in Asia: 1975 or 1908? - Gunboat Diplomacy, Chinese Strategic Mistake, AAA New York, 4(2)

4. Bajrektarević, A. (2019), From WWI to www. - Europe and the World 1918-2018, Addleton Academic Publishers, New York

5. Curtain, P.D. (1984), Cross-Cultural Trade in World History, Cambridge University Press

6. Delantry, G. (1995), Inventing Europe, London, Macmillan

7. Harari, Y.N. (2018), 21 Lessons for the 21st century, Penguin - Random House UK

8. Hobson, J.M. (2004), The Eastern Origins of Western Civilization, Cambridge University Press

9. Kabani, R. (1994), Imperial Fictions: Europe's Myths of Orient, Pandora Books

10. Kipling, R. (1899), The White Man's Burden: The United States and The Philippine Islands, NY 2(99) McClure's Magazine, (reprint, 1934)2.

11. Palacio, A. (2016), Europe on the Sidelines, Project Syndicate (13 Feb 2016, pg.27).

12. Toynbee, A. J. (1934-61), A Study of History, Vol VII: Universal States; Universal Churches (Oxford University Press 1954) and Vol XII: Reconsiderations (Oxford University Press 1961)

13. Wolf, E. R. (1982), Europe and the People Without History, Berkeley: University of California Press

14. Wright, L. (2006), The Looming Tower: Al-Qaeda and the Road to 9/11, First Vintage Books 